\title{
Macroeconomic Determinants of Stock Price in Nigeria
}

\author{
Alphonsus Sunday Anichebe Ph.D, ACA, ACTI \\ Department of Accountancy, Chukwuemeka Odumegwu Ojukwu, University, Igbariam
}

\begin{abstract}
This Study examined the macroeconomic determinants of stock price in Nigeria; using time series data from 1981 to 2017. Data for the study were sourced from the Central Bank of Nigeria Statistical Bulletin. The method adopted in the analysis of data was the Ordinary Least Square (OLS) technique. The results of the estimates showed that the macroeconomic variables have long run relationship with stock price in Nigeria; specifically, the Treasury bill rate has negative impact on stock price in the long run, while Exchange rate, Gross national income and Inflation have positive relationship with stock price in the long run. Recommendations made include, aggressive export diversification by the government and strengthening of demand management measures.
\end{abstract}

Keywords: Stock Price, Exchange Rate, Treasury Bill Rate, Gross National Income, Inflation, Nigeria.

DOI: $10.7176 / \mathrm{EJBM} / 11-21-11$

Publication date:July $31^{\text {st }} 2019$

\section{Introduction}

The Nigerian stock market has grown significantly since inception in 1961 . The growth has been very remarkable since the beginning of the reforms in the country in 1986. Although the depth and breadth of the market, the liquidity and efficiency is still low relative to those of other emerging markets, the market has recorded significant growth in most aggregates in absolute terms. Stock exchanges are expected to accelerate economic growth by increasing liquidity of financial assets and making global risk diversification easier for investors, promoting wiser investment decisions. In principle, a well functioning stock market may help the economic growth and development process in an economy through growth of savings, efficient allocation of investment resources and alluring of foreign portfolio investment.

Financial sector developments and reforms over the years have led to liberalizations and deregulations of markets to facilitate economic growth. Interest in financial markets and the efforts to forecast their performance is as a result of the growing recognition of the increasing impact of macroeconomic variables on these markets.

Aggregate price changes tend to reflect general changes in the state of the economy or shifts in investors' collective expectations. The Arbitrage Pricing policy suggests that variations in macroeconomic variables other than firm specific factors may be responsible for movements in stock prices (Ross, 1976). The macroeconomic variables which are considered important in this regard are exchange rate, inflation, money supply and industrial production. Moreover, the Efficient Market Hypothesis also advocated that stock prices are related to the fundamental macroeconomic indicators ( Fama,1981). The hypothesis also suggested that the prices at the stock market reflect every piece of substantial information that could affect the stock price in any way including the company specific factors, market factors and economic factors.this means that the stock prices should reflect changes in the above macroeconomic variables.

Recent studies on the macroeconomic determinants of stock prices in Nigeria include; Al-shami and Ibrahim (2013) and Masuduzzaman (2012). These studies were carried out in Kuwait and Europe respectively and indicated a long run relationship between stock price movement and the selected macroeconomic variables. Ramadan (2016) and Duy and Hau (2017), carried out in Jordan and Vietnam respectively found that while interest rate has a negative effect on stock prices, money supply has a positive effect. Emmanuel (2018) carried out in Nigeria show that money supply and interest rate has statistically significant effect on stock prices. Udoka, Nya and Bassey (2018) and Malaolu, Ogbuluafor and Orji (2013) all carried out in Nigeria showed no long run relationship between stock price and the macroeconomic variables. There are mixed results from the studies carried out in Nigeria. This may have been due to variations in the choice of methodology by the different studies.

This study therefore seeks to evaluate the macroeconomic determinants of stock price in Nigeria. The remainder of this paper is organised as follows; Section two discusses the literature on macroeconomic determinants of stock price. Section three lays out the analytical framework and econometric methodology. Section four reports the results while section five concludes.

\section{Literature Review}

\subsection{Theoretical Framework}

\subsubsection{Arbitrage pricing theory}

Earlier works on the stock market activity focused mainly on the company specific variables as explanations of the stock price variations. In 1976, Stephen Ross developed Arbitrage Pricing theory of asset pricing, proposing that expected return of an asset or security could be determined by various factors or theoretical market indices 
where sensitivity to changes in each factor is represented by a factor-specific beta coefficient (Ross, 1976). The model-derived rate of return will then be used to price the asset correctly - the asset price should equal the expected end of period price discounted at the rate implied by the model. If the price diverges, arbitrage should bring it back into line.

The return on a stock must follow a very simple relationship that is described by the following formula:

Expected Return $=\mathrm{rf}+\mathrm{b} 1 \times$ (factor 1$)+\mathrm{b} 2 \times($ factor 2$) ..+$ bn $\times($ factor $\mathrm{n})$

Where:

- $\quad \mathrm{rf}=$ the risk free interest rate, which is the interest rate the investor would expect to receive from a riskfree investment.

- $\quad \mathrm{b}=$ the sensitivity of the stock or security to each factor

- $\quad$ factor $=$ the risk premium associated with each entity

Risk Premium $=r-r f=b(1) \times(r$ factor $(1)-r f)+b(2) \times(r$ factor(2) $-r f) \ldots+b(n) \times(r$ factor(n) $-r f)$.

If the expected risk premium on a stock were lower than the calculated risk premium using the formula above, then investors would sell the stock. If the risk premium were higher than the calculated value, then investors would buy the stock until both sides of the equation were in balance.

\section{Factors Used in the Arbitrage Pricing Theory}

The Arbitrage Pricing Theory leaves it up to the investor, or analyst, to identify each of the factors for a particular stock. Therefore, the real challenge for the investor is to identify three items:

- Each of the factors affecting a particular stock

- The expected returns for each of these factors

- The sensitivity of the stock to each of these factors

Ross and others identified the following macro-economic factors they felt played a significant role in explaining the return on a stock; Inflation, GNP or Gross National Product, Investor Confidence, Shifts in the Yield Curve. With that as guidance, the rest of the work is left to the stock analyst (Ross, 1976).

2.1.2 The Efficient-Market Hypothesis (EMH)

The efficient market hypothesis (EMH) was developed by Eugene Fama who argued that asset prices fully reflect all available information (Fama, 1981). A direct implication is that it is impossible to "beat the market" consistently on a risk-adjusted basis since market prices should only react to new information.

There are three variants of the hypothesis: "weak", "semi-strong", and "strong" form. The weak form of the EMH claims that prices on traded assets (e.g., stocks, bonds, or property) already reflect all past publicly available information. The semi-strong form of the EMH claims both that prices reflect all publicly available information and that prices instantly change to reflect new public information. The strong form of the EMH additionally claims that prices instantly reflect even hidden "insider" information.

\subsubsection{Exchange Rate}

Exchange rate is a monetary variable that affect the prices of stock in a way similar to inflation variables. When the domestic currency depreciates against foreign currencies, export product prices will decrease and consequently, the volume of the country's export will increase, assuming that the demand for this product is elastic. The appreciation of a country's currency lowers the cost of imported goods, which in most cases constitute a large part of the production inputs for emerging market countries. According to Pebbles and Wilson (1996), an appreciating currency is generally accompanied by increases in reserves, money supply and a decline in interest rates. The resulting decline in cost of capital and/or imported inputs is expected to lead to an increase in local return. Such an expectation is also consistent with Bilson, Brailsford and Hooperl (2001) conclusion that a devaluation of the domestic currency has a negative relationship with return. Mukherjee and Naka(1995) also confirmed that exchange rate positively relates to Japan and Indonesia stock prices, both two large export countries.

\subsubsection{Interest Rate}

According to Fisher (1930), expected nominal rates of interest on financial assets should move one-to-one with expected inflation. This is referred to as the 'Fisher effect'. Moreover, changes in both short-term and long-term rates are expected to affect the discount rate in the same direction through their effect on the nominal risk-free rate (Mukherjee and Naka, 1995). Interest rates are expected to be inversely related to stock market returns. An increase in interest rate would increase the required rate of return and the stock return would decrease with the increase in the interest rate. An increased rate would raise the opportunity costs of holding cash and the trade off to holding other interest bearing securities would lead to a decrease in share price.

2.2.3 Gross national income

The Gross national income (GNI), previously known as Gross national product (GNP), is the total domestic and foreign output claimed by residents of a country, consisting of gross domestic product (GDP), plus factor incomes earned by foreign residents, minus income earned in the domestic economy by nonresidents Comparing GNI to GDP shows the degree to which a nation's GDP represents domestic or international activity. Unlike gross domestic product (GDP), which defines production based on the geographical location of production, GNP indicates allocated production based on location of ownership. In fact it calculates income by the location of 
ownership and residence, and so its name is also the less ambiguous gross national income. The term gross national income (GNI) has gradually replaced the Gross national product (GNP) in international statistics. While being conceptually identical, the precise calculation method has evolved at the same time as the name change.

2.2.4 Inflation

Inflation is a sustained increase in the general price level of goods and services in an economy over a period of time. When the general price level rises, each unit of currency buys fewer goods and services; consequently, inflation reflects a reduction in the purchasing power per unit of money - a loss of real value in the medium of exchange and unit of account within the economy. A chief measure of price inflation is the inflation rate, the annualized percentage change in a general price index, usually the consumer price index, over time..

The effect of inflation is not distributed evenly in the economy, and as a consequence there are hidden costs to some and benefits to others from this decrease in the purchasing power of money. For example, with inflation, those segments in society which own physical assets, such as property, stock etc., benefit from the price/value of their holdings going up, when those who seek to acquire them will need to pay more for them.

High or unpredictable inflation rates are regarded as harmful to an overall economy. They add inefficiencies in the market, and make it difficult for companies to budget or plan long-term.

\subsection{Review of Previous studies}

Emmanuel (2018) examined the macroeconomic determinants of stock market performance in Nigeria using annual time series data spanning 1981 to 2016. The data were obtained from the Central Bank of Nigeria (CBN) Statistical Bulletin. Four macroeconomic variables, namely: money supply, interest rate, exchange rate and inflation were used as independent variables, while market capitalisation (proxy for stock market performance) was employed as the dependent variable. The results of Augmented Dickey-Fuller (ADF) test revealed that all the variables studied were stationary at first difference except money supply which was stationary at second difference. The Ordinary Least Square (OLS) regression results showed that money supply has a significant positive effect; interest rate has a significant negative effect; whereas, exchange rate and inflation rate have no statistically significant effect on stock market performance in Nigeria. The co integration test results disclosed that there exists a co integrating relationship between the macroeconomic indicators and stock market performance. This implies that there is a long-run relationship between the variables. Therefore, the study concluded that money supply and interest rate are the true determinants of stock market performance in Nigeria.

Al-Shami and Ibrahim (2013), examine the impact of macroeconomic indicators (inflation, interest rate, money supply, oil prices, and unemployment rate) on Kuwait stock market. Basic indicators of Kuwait economy were analyzed using VAR model for the period from January 2001 to Dec 2010 on a monthly basis. A positive association was found between inflation, money supply and oil price in 1-month time and stock return while there is a negative relationship between interest rate in 1-month time and stock return in Kuwait stock market. There is a positive relationship between interest rate in 2-month time and stock return in Kuwait stock market and finally, there is a negative relationship between inflation, money supply and oil prices in 2-month time and stock return in Kuwait stock market.

Masuduzzaman (2012), investigates the long-run relationship and the short-run dynamics among macroeconomic fundamentals and the stock returns of Germany and the United Kingdom. Each case was examined individually, by applying Johansen co-integration, error correction model, variance decomposition and impulse response functions, in a system incorporating the variables such as consumer price index (CPI), interest rates, exchange rates, money supply and industrial productions between the period of February 1999 to January 2011. The Johansen co integration tests indicate that the UK and German stock returns and chosen five macroeconomic variables are co integrated. The findings also indicate that there are both short and long run causal relationships between stock prices and macroeconomic variables. The results imply the existence of short-term adjustments and long-term dynamics for both the UK and the German stock markets returns and the certain macroeconomic fundamentals. The results of the study also indicate that the variables employed in the VARs explain some of the variation of the stock market indices, while the intensity and the magnitude of the responses are comparable with regard to the UK and the German stock markets. Ramadan (2016).aimed to test the effect of macroeconomic factors on the movements of stock prices of Jordanian industrial companies listed in Amman Stock Exchange (ASE). To achieve this objective, all the 77 Jordanian industrial firms listed at ASE for fifteen years from 2000 to 2014 were selected, resulting in 1054 firm-year observations. The unbalanced pooled cross-sectional time series multiple least square regression method was used for the data analysis. Results showed that interest rate and inflation have significant negative effect on the movements of the Jordanian industrial companies stock prices, while the effect of money supply and GDP on the movements of stock prices were significantly positive.

Al.Mutairi and Al.Omar (2013), study the effect of macroeconomic variables on the behaviour of Kuwait stock exchange during the period from 1995 to 2005 using monthly data for both the market and its sub sectors. Interest rate, money supply, inflation, and. government expenditure are the macroeconomic variables used, while market activity was represented by the value of traded shares. Vector auto regression technique is employed to 
achieve this goal. The study indicates that macroeconomic variables have the expected but limited impact on the activities of the Kuwait Stock Exchange. Concerning the size of the macroeconomic variables effect, the results show that the variables have a long run but limited effect. The results indicate, on average, that a negative and long term effect of both interest rate and. inflation, a positive and. long term effect of money supply and a positive and long term effect of government expenditure except for the insurance sector,

Duy and Hau (2017), investigate the macroeconomic determinants of share price in the stock market of Vietnam. The investigation was conducted using a VECM econometric methodology and revealed that Vietnam's stock market prices are chiefly determined by economic activities: market price index, inflation, money supply and exchange rate. An increase in market price index and money supply increases share price, while the increase of inflation (CPI) and exchange rate reduces share price. The study's result showed that Vietnam's stock market can be replaced by investors of foreign currency (USD), while the exchange rate tends to rise.

Nidhi, Banarsidas and Kamini (2013), study the factors that influence stock prices in the context of National Stock Exchange (NSE) New Delhi. The extant literature available strongly supports the movement of stock price as a consequence of firm specific factors such as dividend, book value, earnings etc.. A sample of 95 companies is selected for the period 2007 to 2012 and using linear regression model. The results indicate that firms' book value, earning per share and price-earnings ratio are having a significant positive association with firm's stock price while dividend yield is having a significant inverse association with the market price of the firm's stock.

Udoka, Nya and Bassey (2018), examine the macroeconomic determinants of stock price movements in Nigeria. To achieve this objective, data were gathered on macroeconomic variables such as gross domestic product, exchange rate, inflation, interest rate and absolute stock price were captured for the purpose of analysis. The autoregressive distributive lag (ARDL) model was used in analyzing the macroeconomic determinants of stock price movement in Nigeria. The augmented Dickey-Fuller (ADF) unit root test was also engaged in order to ascertain the stationarity or otherwise of the variables. The ARDL findings revealed that the variables GDP, Exchange rate, Interest rate and Inflation were not jointly co-integrated with the dependent variable stock price, hence, no long run relationship exists. Conclusively, there was no long run relationship between macroeconomic determinants and stock price movements in Nigeria.

Mohammed and Evana (2015), examine the relationship between stock price, dividend and retained earnings of 29 listed banks of Chittagong Stock Exchange, in the post-crash period. Cross-sectional data were collected from secondary sources. Using linear regression method, the study found that both, dividend and retained earnings of sample banks have strong influence over the stock price, though there was moderate explanatory power of those variables.

Malaolu, Ogbuabor and Orji (2013), examine the macroeconomic determinants of stock price movements in Nigeria using detailed econometric framework in order to provide the foundation for evidence-based policies. Both the long-run and short run dynamic relationships between the stock price movement and the macroeconomic variables were analyzed with time series data that spanned from 1985 to 2010 using the Engle-Granger two-step co integration test. The study established that there is no co integration between the variables, indicating the absence of long run relationship. Results also indicate that the monetary policy variables (real exchange rate, real interest rate and money supply) as well as political instability are not the determinants of stock price movements in Nigeria; however, inflation was found to be a major determinant of stock price movement.

Eita (2011), investigates the macroeconomic determinants of stock market prices in Namibia. The investigation was conducted using a VECM econometric methodology and revealed that Namibian stock market prices are chiefly determined by economic activity, interest rates, inflation, money supply and exchange rates. An increase in economic activity and the money supply increases stock market prices, while increases in inflation and interest rates decrease stock prices. The results suggest that equities are not a hedge against inflation in Namibia, and contractionary monetary policy generally depresses stock prices. Increasing economic activity promotes stock market price development.

Oyama (1997), examines the general relationship between stock prices and macroeconomic variables in Zimbabwe, using the revised dividend discount model, error- correction model, and multi-factor return-generating model. Despite the large fluctuation in stock prices since 1991, this analysis indicates that the Zimbabwe stock exchange has been functioning quite consistently during this period. Whereas sharp increases in stock prices during 1993-94 were mainly due to the shift of risk premium that was caused by the partial capital account liberalization, the recent rapid increase in stock prices can be explained by the movements of monetary aggregates and market interest rates.

\section{Methodology \\ 3.1 Data}

The investigation into the macroeconomic determinants of stock price in Nigeria was based on a quantitative design framework and covered the period from 1985 to 2017. All data variables were sourced from the Central Bank of Nigeria Statistical Bulletin (various editions) 
Four macroeconomic variables, namely; Exchange rate, Interest rate, Inflation and Gross national income were selected as critical variables for this study. The study based its selection of variables on theoretical proposition and evidence in the literature.

\subsection{Model specification.}

The model expressed the stock price as the dependent variable while the independent variables include; exchange rate, interest rate (proxied by Treasury bill rate), inflation and gross national income.

$\mathrm{Stp}=\mathrm{f}($ exr, tbr, inf, gni)

This can be expressed more appropriately as follows;

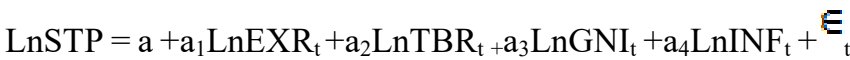

Where:

$\mathrm{STP}=$ Stock price proxied by the NSE All share index

$\mathrm{EXR}=$ Nominal effective exchange rate, expressed in naira per unit of US dollar

$\mathrm{TBR}=$ The 91-day treasury bill rate is used as proxy for interest rate, since Treasury bill serves as the opportunity cost of holding shares and as a benchmark for measuring interest rate.

$\mathrm{GNI}=$ The Gross national income is used in place of the gross national product

$\mathrm{INF}=$ Inflation

$\mathbf{E}_{\mathrm{t}}=$ Random error term

$\mathrm{a}=$ Constant

$\mathrm{a}_{1}, \mathrm{a}_{2}, \mathrm{a}_{3}$ and $\mathrm{a}_{4}$ are the coefficients of the regression equation.

\subsection{Estimation Procedures}

- The characteristics of the time series data used in the analysis are first evaluated. The statistical properties of the variables provide information about the means, medians, standard deviations, skewness, kurtosis and jarque-Bera statistics of each variable. Standard deviation measures dispersion in the series. Skewness measures asymmetry of the distribution of the series around its mean and it is expected to be zero for normal distribution. Kurtosis measures the peakedness or flatness of the distribution of the series while Jarque-Bera is a test statistic for testing whether the series is normally distributed. The test statistic measures the difference of the skewness and kurtosis of the series with those from the normal distribution. The correlation analysis that shows the extent of linear relationship that exist among variables is employed to estimate the nature of linear association among the variables.

- $\quad$ Thereafter, the stationarity properties of the employed data are examined using the Augmented DickeyFuller test.

- The existence of a stationary linear combination from the non-stationary time series is referred to as co integration and it can be interpreted as a long-run equilibrium relationship among the variables.

- $\quad$ The long run analysis is estimated using Ordinary Least Square (OLS) estimation technique.

\section{Results and Discussion}

\subsection{Descriptive statistics}

The characteristics of the time series data used in the analysis are presented in Table 4.1. The variables are systematically distributed. The outcomes of each variable's mean, median as well as values for their maximum and minimum suggest that the variables are well behaved. The mean values of all the variables employed are not too different from their respective median values. This is an indication of absence of excessive outliers and stability of the variables employed, which are essential for the analyses carried out in this study. The value of the standard deviation of each of the variables is a further proof of the fact that the distribution of the variables is approaching normal distribution. In addition, the skewness, kurtosis and standard deviation statistics show that the variances of the variables are not unnecessarily large. 
Table 4.1 Descriptive Statistics

\begin{tabular}{lccccc}
\hline & EXR & GNI & INF & STP & TBR \\
\hline Mean & 66.64848 & 23877361 & 19.94576 & 15839.78 & 13.68152 \\
Median & 81.30000 & 4454010. & 12.20000 & 10963.10 & 12.95000 \\
Maximum & 158.0700 & $1.03 \mathrm{E}+08$ & 76.80000 & 57990.20 & 26.90000 \\
Minimum & 0.740000 & 69760.22 & 0.200000 & 127.3000 & 4.500000 \\
Std. Dev. & 45.33957 & 34198840 & 19.15983 & 15234.39 & 4.765431 \\
Skewness & -0.181863 & 1.296872 & 1.628122 & 0.766248 & 0.320495 \\
Kurtosis & 1.772110 & 3.104239 & 4.510597 & 2.853875 & 3.316597 \\
Jarque-Bera & 2.255013 & 9.265261 & 17.71691 & 3.258606 & 0.702765 \\
Probability & 0.323840 & 0.009729 & 0.000142 & 0.196066 & 0.703714 \\
Observations & 33 & 33 & 33 & 33 & 33 \\
\hline Source: Author & & & & & 3
\end{tabular}

Source: Author's Computation

\subsection{Correlation Analysis}

The correlation matrix of the variables employed in this Study is presented in Table 4.2. The table presented all possible bivariate combinations of all the employed variables. The result as presented in Table 4.2 showed that most of the variables employed are highly correlated. The directions of the correlation for some are positive, while negative for some variables.

\begin{tabular}{|c|c|c|c|c|c|}
\hline & FXR & GNI & INF & STD & TD \\
\hline EXR & 1.000000 & 0.665396 & -0.603019 & 0769774 & 20177153 \\
\hline GNI & 0.665396 & 1.000000 & -0.289027 & 0.683813 & 0.205645 \\
\hline INF & -0.603019 & -0.289027 & 1.000000 & -0.415084 & 0.300131 \\
\hline STP & 0.769774 & 0.683813 & -0.415084 & 1.000000 & -0.220035 \\
\hline TBR & -0.177153 & 0.205645 & 0.300131 & -0.220035 & 1.000000 \\
\hline
\end{tabular}

Source: Author's Computation

\subsection{Unit Root/ Stationarity test}

The variables employed in the analysis are tested for stationarity using the Augmented Dickey-Fuller test. The results of the unit root tests as presented in Table 4.3 indicated that all the variables are stationary at after first difference with the exception of gross national income which is stationary at after second difference.

Table 4.3. The Unit Root Test Results for the Selected Variables

\begin{tabular}{|c|c|c|c|}
\hline Variables & & Augmented Dickey-Fuller test & Conclusion \\
\hline \multirow[t]{2}{*}{ TBR } & Level & -2.660731 & $\mathrm{I}(1)$ \\
\hline & $1^{\text {st }}$ Difference & -5.043064 & \\
\hline \multirow[t]{2}{*}{ LSTP } & Level & -1.269828 & \multirow[t]{2}{*}{$\mathrm{I}(1)$} \\
\hline & $1^{\text {st }}$ Difference & -5.642234 & \\
\hline \multirow[t]{2}{*}{ LGNI } & Level & 1.966804 & \multirow[t]{2}{*}{$\mathrm{I}(2)$} \\
\hline & $2^{\text {nd }}$ Difference & -5.783605 & \\
\hline \multirow[t]{2}{*}{ LEXR } & Level & -0.277962 & \multirow[t]{2}{*}{$\mathrm{I}(1)$} \\
\hline & $1^{\text {st }}$ Difference & -4.213063 & \\
\hline \multirow[t]{2}{*}{ LINF } & Level & -3.827247 & \multirow[t]{2}{*}{$\mathrm{I}(1)$} \\
\hline & $1^{\text {st }} \quad$ Difference & -5.108268 & \\
\hline
\end{tabular}

Source: Author's Computation

\subsection{Tests for Co-integration}

Co-integration tests are carried out to ascertain the existence of long run relationship among the variables employed for each model.

Table 4.4 illustrates the outcome of the co-integration test. There are two co-integrating relations among the variables in the model as indicated by the Max-Eigen Statistic. This implies that there are long run relations among the variables employed in the model.

Table 4.4 Test of Co-integration among LSTP, TBR, LEXR, LGNI and LINF

\begin{tabular}{ccccc}
\hline \hline Eigenvalue & $\begin{array}{c}\text { Likelihood } \\
\text { Ratio }\end{array}$ & $\begin{array}{c}\text { 5 Percent } \\
\text { Critical Value }\end{array}$ & $\begin{array}{c}\text { 1 Percent } \\
\text { Critical Value }\end{array}$ & $\begin{array}{c}\text { Hypothesized } \\
\text { No. of CE(s) }\end{array}$ \\
\hline \hline 0.623797 & 79.20209 & 68.52 & 76.07 & None **
\end{tabular}




\begin{tabular}{lrrrl}
0.548888 & 48.89568 & 47.21 & 54.46 & At most 1 * \\
0.384616 & 24.21841 & 29.68 & 35.65 & At most 2 \\
0.208716 & 9.167643 & 15.41 & 20.04 & At most 3 \\
0.059771 & 1.910600 & 3.76 & 6.65 & At most 4 \\
\hline
\end{tabular}

$*(* *)$ denotes rejection of the hypothesis at $5 \%(1 \%)$ significance level L.R. test indicates 2 co integrating equation(s) at $5 \%$ significance level

\subsection{Results of the Estimated Model}

The result of the model as presented in the table show that, LEXR, LGNI and LINF have positive impact on LSTP while TBR has negative impact on LSTP. All the explanatory variables included in the model are statistically significant except LINF.

Of interest is the fact that 64.7 per cent of the variations in the LSTP are explained by TBR, LEXR, LGNI and LINF as implied by the Adjusted $\mathrm{R}^{2}$. The LSTP model is statistically significant as implied by the significance of the F-statistics coefficient in the model.

Table 4.5 Estimated Results

\begin{tabular}{|c|c|c|c|c|}
\hline Variable & Coefficient & Std. Error & t-Statistic & Prob. \\
\hline $\mathrm{C}$ & 10039.52 & 7268.684 & 1.381202 & 0.1781 \\
\hline EXR & 161.6572 & 60.05394 & 2.691866 & 0.0119 \\
\hline GNI & 0.000194 & $7.00 \mathrm{E}-05$ & 2.775080 & 0.0097 \\
\hline INF & 59.86959 & 108.3544 & 0.552535 & 0.5850 \\
\hline TBR & -790.0008 & 386.2530 & -2.045293 & 0.0503 \\
\hline$\overline{R \text { R-squared }}$ & 0.691791 & Mean dependent var & & $\overline{15839.78}$ \\
\hline Adjusted R-squared & 0.647761 & S.D. dependent var & & 15234.39 \\
\hline S.E. of regression & 9041.565 & Akaike info criterion & & 21.19578 \\
\hline Sum squared resid & $2.29 \mathrm{E}+09$ & Schwarz criterion & & 21.42252 \\
\hline Log likelihood & -344.7304 & F-statistic & & 15.71186 \\
\hline Durbin-Watson stat & 0.966390 & Prob(F-statistic) & & 0.000001 \\
\hline
\end{tabular}

\section{Discussion}

i Results of the analysis indicated a negative relationship between interest rate as proxied by the treasury bill rate and stock price. This means that increases in interest rates adversely affects stock price. As interest rate rises, stock price falls. This result is also significant. Interest rates are expected to be inversely related to stock market returns. An increase in interest rate would increase the required rate of return and the stock return would decrease with the increase in the interest rate. An increased rate would raise the opportunity costs of holding cash and the trade off to holding other interest bearing securities would lead to a decrease in share price.

ii The results also indicated a strong positive relationship between Exchange rate, Gross national income and stock price. This means that depreciation of the naira exchange rate pushes up the stock price. Again, an increase in the Gross national income leads to a rise in stock price. Mukherjee and Naka(1995) also confirmed that exchange rate positively relates to Japan and Indonesia stock prices, both two large export countries. An increase in economic activity also benefits stock market prices.

Inflation is also positively related to stock price, though the effect is not strong. A rise in the general price level also leads to a rise in the stock price.

\subsection{Conclusion}

This study investigated the macroeconomic determinants of stock price in Nigeria over the period 1985 to 2017. It estimated a multivariate APT model with the dependent variable as the stock price (proxied by the NSE all share index). The study was carried out through a review of the relevant theoretical and empirical literature and employed secondary data sourced from the Central bank of Nigeria statistical bulletins for the relevant period. The model for the study was analysed using the Ordinary least square technique. Results of the analysis indicate a long run relationship between stock price and the explanatory variables. Interest rate shows a strong negative effect on stock price while exchange rate and the gross national income have a strong positive relationship with stock price. Inflation has a positive non significant impact on stock price. The findings of this study confirm the propositions of the Arbitrage Pricing theory as well as the Efficient market hypothesis. 


\subsection{Recommendations}

i. There is need for a more aggressive export diversification. This will enhance net resource inflow, dampen further domestic inflationary pressure and a move towards a more effective liberalization which would reduce resource outflows.

ii. Strengthening of demand management measures. These entail a sustained and concerted action to achieve fiscal viability on the short run, and this includes efficient revenue mobilization and less dependence of the government on the Central bank and banking system financing of the fiscal deficits.

\section{References}

Al.Mutairi, A. \& Al.Omar, H. (2013).Macroeconomic Determinants of the behaviour of Kuwait Stock Exchange. Studies in Business and Economics. Vol. 13, No. 1, Pp. 39-50.

Al-Shami H. A. A. \& Ibrahim Y.(2013) The Effects of Macro-economic Indicators on Stock Returns: Evidence from Kuwait Stock Market. American Journal of Economics. 3(5C):57-66.

Bilson, C.M, Brailsford, T.J. \& Hooper, V.J. (2001). Selecting Macroeconomic Variables as Explanatory Factors of Emerging Stock Market Returns. Pacific Bason Finance Journal, 9 (4): 401-426.

Duy, V.Q. \& Hau, L.(2017). Impact of Macroeconomic Factors on Share Price Index in Vietnam's Stock Market.The International Journal of Engineering And Science (IJES), Volume 6, Issue 1, Pp. 52-59.

Eita, J.H. (2011). Determinants of Stock Market Prices in Namibia. Monash University Working Paper 209 March 2011, PP. 1-16.

Emmanuel, I.J.(2018). Macroeconomic Determinants of Stock Market Performance in Nigeria: An Econometric Approach. Indonesian Journal of Applied Business and Economic Research, Vol. 1, No. 1, pp. 47-58.

Fama, E.F. (1981), Stock Returns, Real Activity, Inflation and Money. American Economic Review, 71(4): 545 565.

Fisher, I. (1930). The Rate of Interest. New York. Macmillan.

Malaolu, V.A., Ogbuabor, J.E. \& Orji, A. (2013). Determinants of Stock Price Movements in Nigeria: Evidence from Monetary Variables. Journal of Economics and Sustainable Development, Vol.4, No.14, Pp61-66.

Masuduzzaman, M.(2012). Impact of the Macroeconomic Variables on the Stock Market Returns: The Case of Germany and the United Kingdom. Global Journal of Management and Business Research Volume 12 Issue 16 Version 1.0. pp. 23-34.

Mohammed, S. I. \& Evana, N. D. (2015) Determinants of Stock Price Movements: Evidence from Chittagong Stock Exchange, Bangladesh. Journal of Economics and Business Research, Volume XXI, No. 2, pp. 117-133.

Mukherjee, T.K. \& Naka, A. (1995). Dynamic Reactions between Macroeconomic Variables and the Japanese Stock Market: An Application of Vector Error Correction Model. The Journal of Financial Research, XVIII (2), 223-237.

Nidhi, M., Banarsidas, C. \& Kamini, T. (2013) .Determinants of Stock Prices: Empirical Evidence from NSE 100 Companies. International Journal of Research in Management \& Technology (IJRMT), Vol. 3,No.3. pp 8695.

Oyama, T.(1997). Determinants of stock prices: the case of Zimbabwe. International monetary fund Policy Development and Review working paper WP/07/117. Pp. 1-44.

Pebbles, G. \& Wilson, P. (1996).The Singapore Economy. Cheltenham, UK. Edward Elgar.

Ramadan, I. Z.(2016).Macroeconomic Approach of the Determinants of Stock Price Movements in Jordan. Asian Journal of Finance \& Accounting. Vol. 8, No. 2. Pp.60-69.

Ross, S. (1976). The Arbitrage Theory of Capital Asset Pricing. Journal of Economic Theory, 13: 340-362.

Udoka, C.O.,Nya, M.J. \& Bassey. J.G. (2018). The Effect Of Macroeconomic Determinants Of Stock Price Movements In Nigeria. International Journal of Research-Granthaalayah. ., Vol.6 (Iss. 1):Pp. 203-218. 